\title{
Effect of Different Reinforced Type on RC Beams
}

\author{
Amr Ali $^{*}$, Ahmed Hassan ${ }^{* *}$, Nasr. Z. Hassan ${ }^{* * *}$ and Hala Mamdouh ${ }^{* * *}$ \\ *M.Sc. student, Department of Civil Engineering, Helwan University, Cairo, Egypt. \\ ** Professor, faculty of Engineering, Beni-Suef University, Beni-Suef, Egypt. \\ **** Associate professor, faculty of Engineering-Mataria, Helwan University, Cairo, Egypt.
}

\begin{abstract}
In the last few decades, Fiber-Reinforced Polymers (FRP) bars have emerged as alternatives to conventional steel reinforcing bars to overcome the corrosion problem found in reinforced concrete structures. Fiber Reinforced polymer (FRP) is a new material, so it is necessary to identify the differences and limitations of their use in the concrete structures in relation to traditional steel reinforcement of concrete structures. Numerous studies have been conducted in order to evaluate the bond between FRP bars and concrete. This paper presents the test results of a study on the bond behavior of simply supported beams under flexure, reinforced with FRP bars (BFRP and GFRP) compared to the reference beam with steel reinforcement. The tested beams were made of C 40 concrete and reinforced with bars with $10 \mathrm{~mm}$ diameter having and tensile strength evaluated from the tensile tests. The analysis of the beam deflection behavior has been presented. The results show the different character of the load-deflection relationship of FRP reinforced beams compared to traditionally steel reinforced beams.
\end{abstract}

Keywords: Reinforced concrete beams, Fiber reinforced polymer, flexural capacity, bond.

\section{Introduction:}

Steel is being used as a reinforcing material in the construction industry for more than a century. However, Deterioration of RC structures due to corrosion of reinforcing steel bars is a major concern [1]. Increasing concrete cover or reducing the permeability of concrete by adding pozzolanic materials, protects the steel bars against corrosion. However, as the cracks develop on the surface of RC structures, they are exposed to oxygen and humidity which causes corrosion and deterioration. Many steel-RC structures such as bridges, parking garages and marine structures are exposed to harsh environments including deicing salts, freeze-thaw cycles and wet-dry cycles. Such aggressive environments accelerate the steel-corrosion process due to the accumulation of chloride ions. The use of corrosion resistant material seems to be the only effective alternative. The corrosion problem of steel bar is the greatest factor in limiting the life expectancy of RC structures. Many environmental conditions accelerate the corrosion process of steel bar; thereby resulting in steady deterioration that decreases the life expectancy of these structures. Several measures have been adopted, to enhance the corrosion resistivity of steel such as epoxy coating of steel, use of stainless steel (low 
carbon steel) and galvanization of steel bars. Despite the application of these measures, none of them is successful in completely eliminating the corrosion, in recent years, considerable efforts have been made to apply FRP composites in the construction industry, and recently, structural applications of FRP composites started to appear in civil infrastructure systems [2]. FRP composite materials have been used as internal and external reinforcement as a replacement of steel in the field of civil engineering constructions [3]. Considerable research efforts have contributed to the understanding of concrete members internally reinforced with FRP bars [4]. These efforts, greatly improving our knowledge of how concrete members Reinforced with FRP bars should be analyzed and designed in flexure. In recent years, significant research efforts have shown that FRP materials can be effectively used to reinforce RC structures [5-9]. Normal FRP reinforcements are usually manufactured using Pultruded fibres (carbon, glass and aramid) bound together with a resin matrix. A new type of material (basalt fibres) has been used to produce basalt fibre-reinforced polymer (BFRP). With the higher mechanical performance, especially chemical resistance (compared with GFRP bars), and lower price (than CFRP bars). The main Advantages and disadvantages of FRP reinforcement against steel are shown in Table (1) [10-11].

Table-1. Main advantages and disadvantages of FRP reinforcement

\begin{tabular}{|l|l|}
\hline \multicolumn{1}{|c|}{ Advantages of FRP reinforcement } & Disadvantages of FRP reinforcement \\
\hline $\begin{array}{l}\text { High longitudinal tensile strength (varies with } \\
\text { sign and direction of loading relative to fibers) }\end{array}$ & $\begin{array}{l}\text { Low modulus of elasticity (varies with type } \\
\text { of reinforcing fiber) }\end{array}$ \\
\hline $\begin{array}{l}\text { Lightweight (about } 1 / 5 \text { to } 1 / 4 \text { the density of } \\
\text { steel) }\end{array}$ & $\begin{array}{l}\text { Low transverse strength (varies with sign and } \\
\text { direction of loading relative to fibers) }\end{array}$ \\
\hline Nonmagnetic & No yielding before brittle rupture \\
\hline Corrosion resistance & Low durability in a moist environment \\
\hline Low thermal and electric conductivity & $\begin{array}{l}\text { May be susceptible to fire depending on matrix } \\
\text { type and concrete cover thickness }\end{array}$ \\
\hline
\end{tabular}

In the previous years, there have been several achievements worldwide from studies of FRP bars' basic mechanical properties, and FRP bar-reinforced concrete's structural properties, bond properties and anchorage techniques, durability and ductility. These studies include bond mechanism of FRP rebars to concrete [12], stress properties and failure mode for FRP bar-reinforced concrete beams [13-14], experimental studies of beam shear capacities [15-16], studies of anchorage length and strength of FRP bars [1718], predicting the bond strength of glass fibre-reinforced polymer (GFRP) bars in concrete with artificial neural network and genetic programming [19], and studies of the properties of mixed FRP reinforcement (mixed with different fibres) [20]. In recent years, studies on concrete beams reinforced with basalt FRP bars have been the focus for some researchers [21-26]. 
The main objectives of this study are investigate and to better understand the behavior of FRP bars for concrete beams compared to steel bars under flexural loading through an experimental and numerical programs. As well as Provide recommendations and guidelines for the designers and researchers regarding the analysis and design of FRP reinforced beams.

\section{Research Program:}

\subsection{Specifications of Test Specimens}

The research program contained a bending test of one model beams with bottom reinforcement made of BFRP bars and one model beams with bottom reinforcement made of GFRP bars, for comparison, a bending test of one simply supported reference beams with a traditional bottom reinforcement made of in the form of a traditional bottom steel bars. All cast beams have the same Reinforcement consisted of two reinforcing bars with a diameter of $10 \mathrm{~mm}$. All beams had a rectangular cross section of $150 \times 300 \mathrm{~mm}$. The total length and effective span of each beam was 1600 and $1500 \mathrm{~mm}$ respectively.in all the beams steel stirrups for shear having a diameter of 8 $\mathrm{mm}$ have been provided. Top reinforcement in all tested beams consisted of two steel bars with a diameter of $10 \mathrm{~mm}$.

\subsection{Material Properties:}

A normal weight ready mixed concrete was used to cast the test specimens. The target 28-day concrete compressive strength was $40 \mathrm{MPa}$ with a maximum aggregate size of $20 \mathrm{~mm}$. Table (2) shown the Concrete mix proportions.

Table 2: Concrete mix proportions

\begin{tabular}{|c|c|c|c|c|c|}
\hline fcu & Cement & $\begin{array}{c}\text { Coarse } \\
\text { Aggregate } \\
\left(\mathbf{M g} / \mathbf{m}^{\mathbf{3}}\right)\end{array}$ & $\begin{array}{c}\text { Fine } \\
\text { Aggregate } \\
\left(\mathbf{~ k g} / \mathbf{m}^{\mathbf{3}}\right)\end{array}$ & $\begin{array}{c}\text { Water } \\
\left(\mathbf{~ k g} / \mathbf{m}^{\mathbf{3}}\right)\end{array}$ & $\begin{array}{c}\text { Basef } \\
\text { Superplasticizer } \\
\left(\mathbf{L t s} / \mathbf{m}^{\mathbf{3}}\right)\end{array}$ \\
\hline 40 & 450 & 1130 & 650 & 188 & 8 \\
\hline
\end{tabular}

Deformed steel bars were used for the steel-RC specimen, whereas for the BFRP-RC specimen, BFRP bars and for the GFRP-RC specimen, GFRP bars were used as longitudinal reinforcement. The mechanical properties of the used steel and FRP bars were obtained through tensile tests Table (3) provides the mechanical properties of the steel and FRP reinforcement used in this study. 
Table 3: Mechanical properties of reinforcing bars

\begin{tabular}{|cc|c|c|c|}
\hline $\begin{array}{c}\text { Bar size } \\
(\mathbf{m m})\end{array}$ & $\begin{array}{c}\text { Modulus of elasticity } \\
(\text { MPa. })\end{array}$ & $\begin{array}{c}\text { Tensile strength } \\
(\mathbf{M p a})\end{array}$ & $\begin{array}{c}\text { Ultimate strain } \\
(\%)\end{array}$ \\
\hline $\mathbf{1 0}$ & Steel & 200,000 & 732.5 & 0.23 \\
\hline $\mathbf{1 0}$ & BFRP & 82,000 & 940 & 1.38 \\
\hline $\mathbf{1 0}$ & GFRP & 37,000 & 550 & 2.18 \\
\hline
\end{tabular}

\section{$\underline{2.3 \text { Test Setup, Instrumentation and Loading: }}$}

The beams were tested under one-point bending load, as shown in Figure (1). The load was applied through a $1000 \mathrm{KN}$ MTS actuator at a stroke-controlled rate of 1.2 $\mathrm{mm} / \mathrm{min}$. Figure 1 provides a schematic illustration of the test setup. The displacement was monitored with three linear variable differential transformers (LVDTs); one was placed at the midspan and two were placed at quarter- span from left and right side. During the test, the beam cracking patterns were marked visually, and their corresponding loads were recorded. Two electrical resistance strain gauges $(6 \mathrm{~mm}$ and $60 \mathrm{~mm}$ ) were used to measure the strains in bars and concrete respectively. The tests were conducted in the structural engineering faculty of the Civil Engineering Laboratories in faculty of Engineering El-Materia, HELWAN UNIVERSITY.

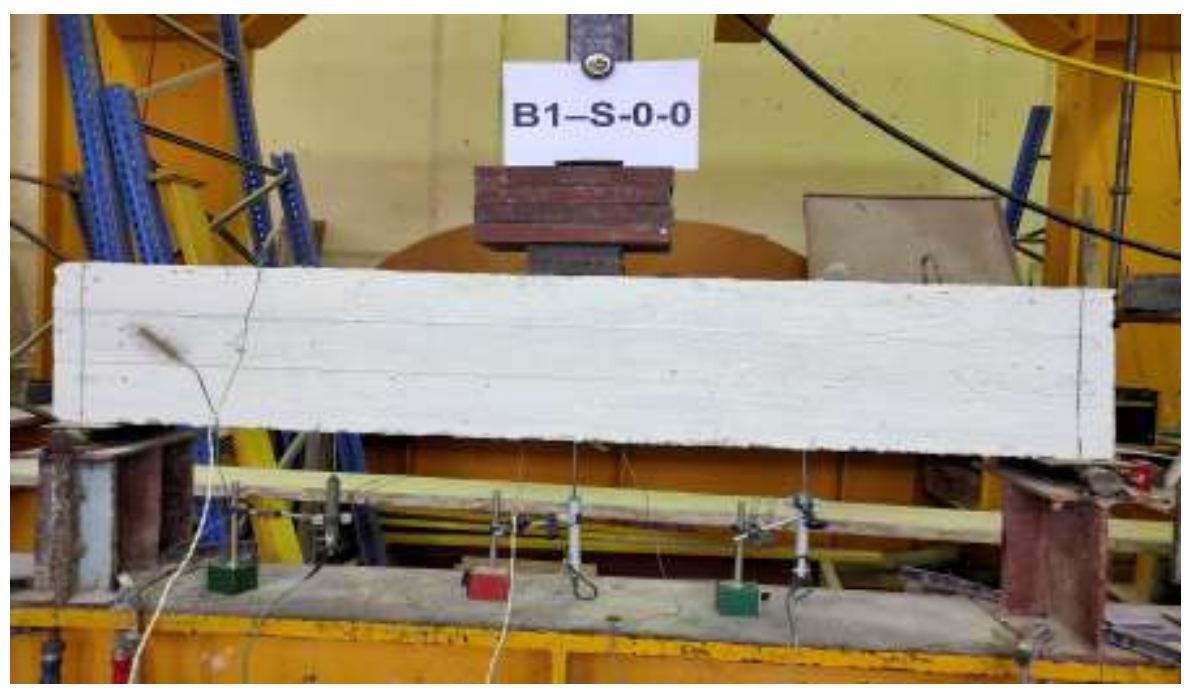

Figure (1): Test Setup and Beams under Testing.

\section{$\underline{\text { 3. Results and Discussion }}$}

\subsection{Cracks Pattern and Failure Mode:}

As shown in Figure (2) through Figure (4), all tested beams failed in flexure. During testing, the cracks started with initial cracks in the middle of the constant moment zone of the beam. As loading increased, more cracks at moment region were 
formed and cracks became wider and increased in length towards the compression zone. Cracks at moment region continued to widen as the load increased causing flexural failure. Failure occurred due to Longitudinal splitting of the concrete around the bars occurs due to the radial forces of the bar ribs or surface deformation. The radial forces cause circumferential tensile stresses in the concrete surrounding the bar. Then, the cracks occur at the locations with the thinnest concrete cover around the bars as shown in Figure (5). We can see also the cracks symmetrical and distributed uniformly. As well as it is noticed that Using FRP bars instead of steel bars in RC beams reduced the cracks, width and spreading.

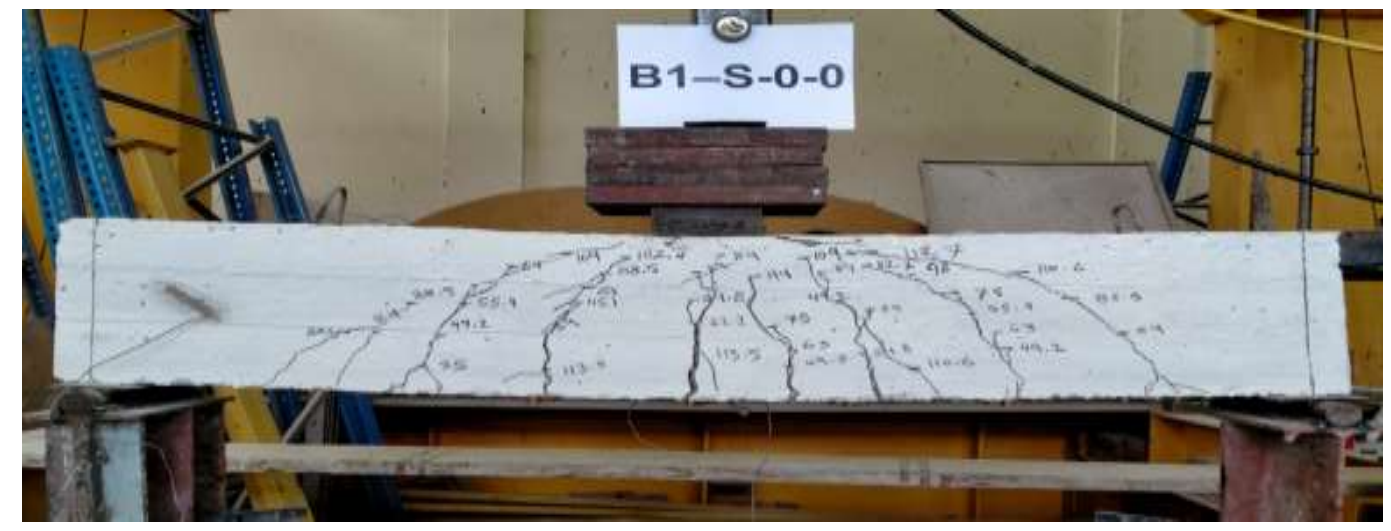

Figure (2): Cracks for Beam (S-0-0) at Failure

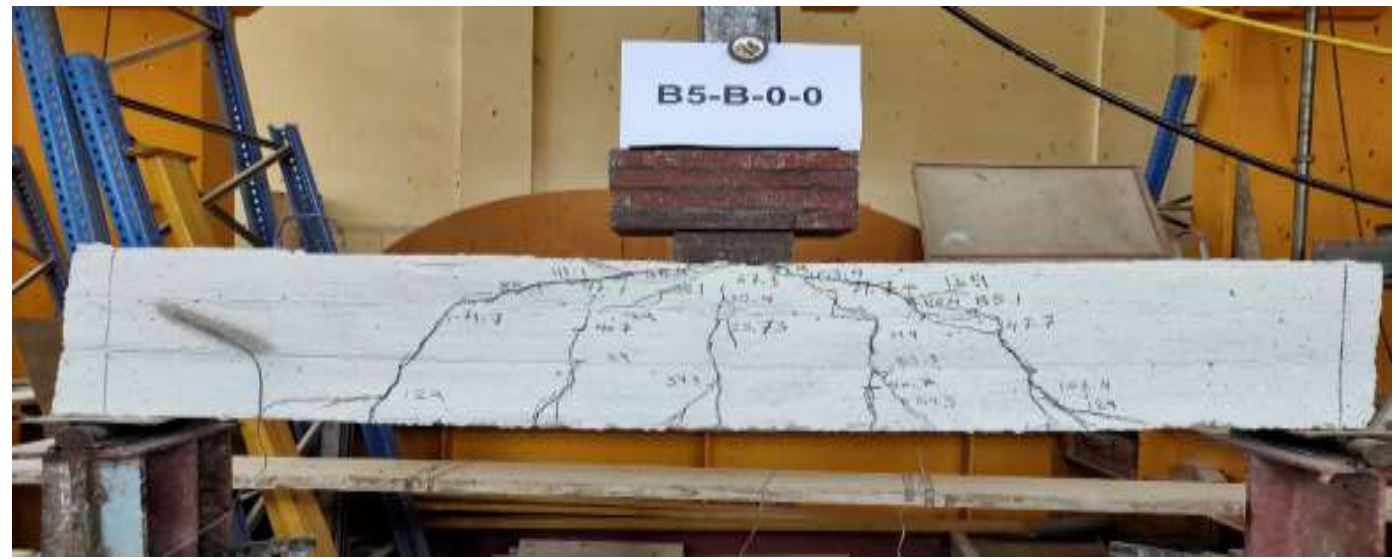

Figure (3): Cracks for Beam (B-0-0) at Failure

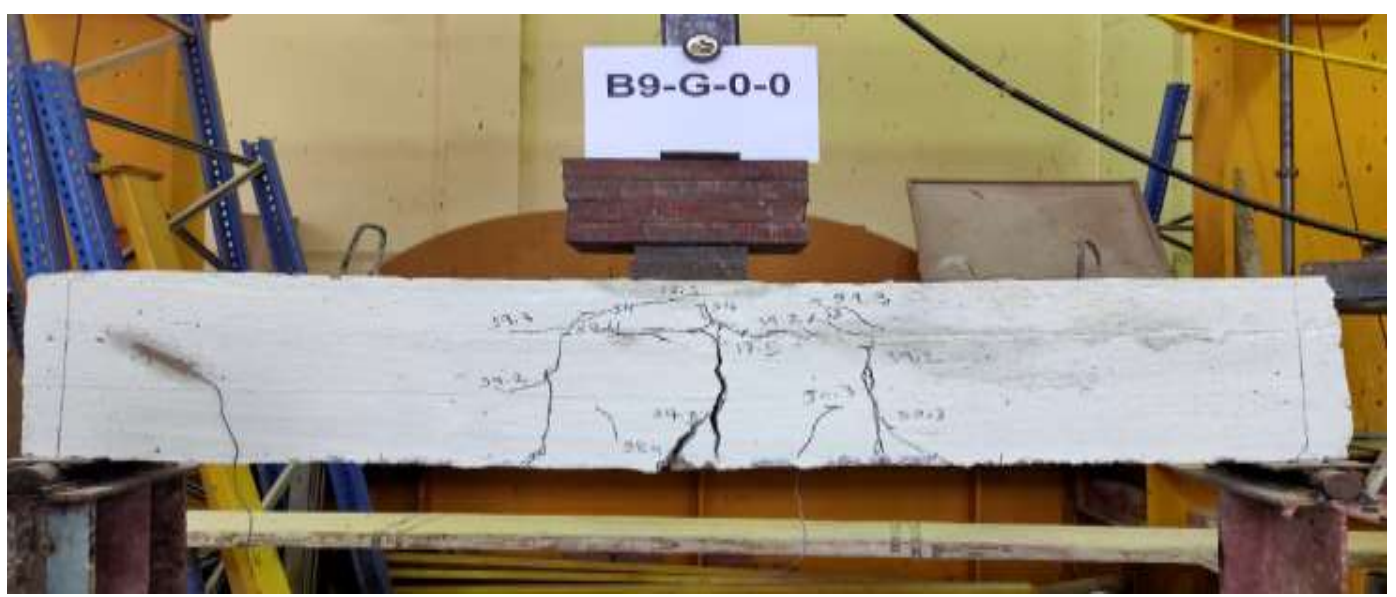

Figure (4): Cracks for Beam (G-0-0) at Failure 


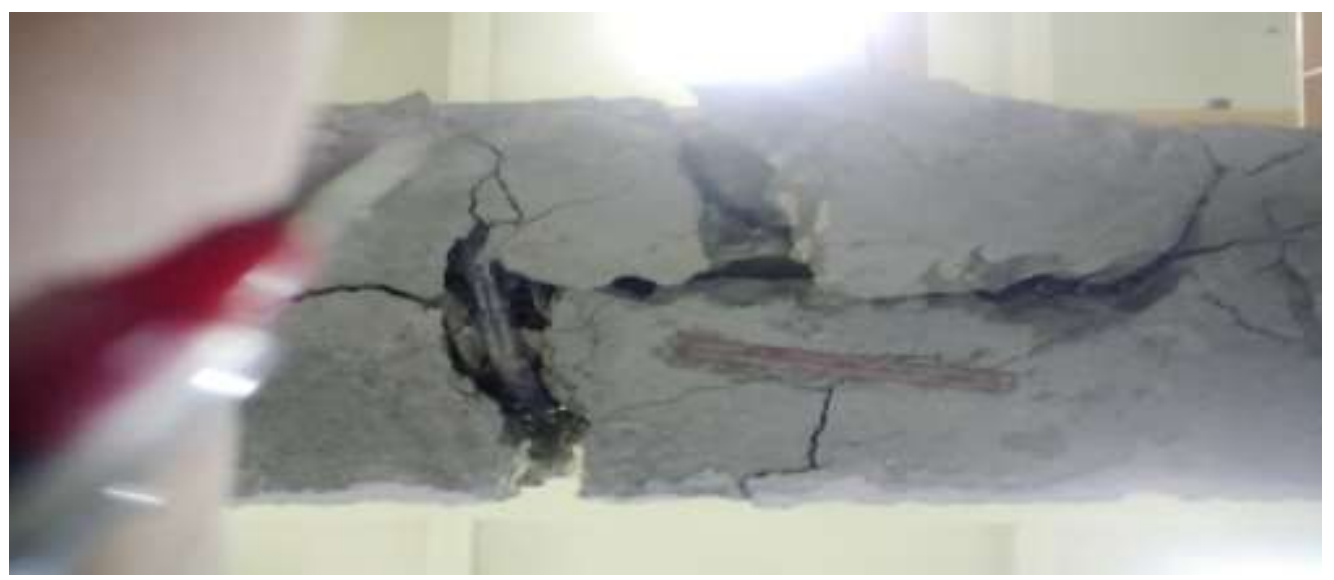

Figure (5): Typical Splitting Failure of Concrete in the Tension Zone

\subsection{Deflection Response}

Table 4 presents the results of experimentally obtained of the tested BFRP and GFRP beams compared to the reference beam with steel reinforcement.

Table (4): Comparing Results of beams (B-0-0), (G-0-0) and (S-0-0)

\begin{tabular}{|c|c|c|c|c|}
\hline Beam & $\begin{array}{c}\text { Reinforcement } \\
\text { Type }\end{array}$ & $\begin{array}{c}\mathbf{P}_{\max } \\
(\mathbf{K N})\end{array}$ & $\begin{array}{c}\Delta_{\max } \\
(\mathbf{m m})\end{array}$ & $\begin{array}{c}\text { Failure } \\
\text { Type }\end{array}$ \\
\cline { 1 - 4 } S-0-0 & Steel & 44.20 & 14.25 & \multirow{2}{*}{ Flexure } \\
\cline { 1 - 4 } B-0-0 & BFRP & 40.60 & 10.18 & \\
\cline { 1 - 4 } G-0-0 & GFRP & 30.90 & 16.43 & \\
\hline
\end{tabular}

From Figure (6) and Table (4) by Comparing Results of beams [(B-0-0) reinforced with BFRP bars] and [(G-0-0) reinforced with GFRP bars] with control beam [(S-0-0) reinforced with Steel bars]. It was found that:

- Load carrying capacity of tested beam (B-0-0) is decreased with percentage $8.14 \%$ than control beam (S-0-0). And its deflection decreased with percentage $28.56 \%$.

- Load carrying capacity of tested beam (G-0-0) is decreased with percentage $30.10 \%$ than control beam (S-0-0). While its deflection increased with percentage $15.30 \%$.

It was noted that load capacity for tested beams reinforced with FRP bars were lower than the carrying capacity of beams with conventional steel reinforcement. But at the same load, its deflection was higher. Similar annotations were found by [27-28]. 


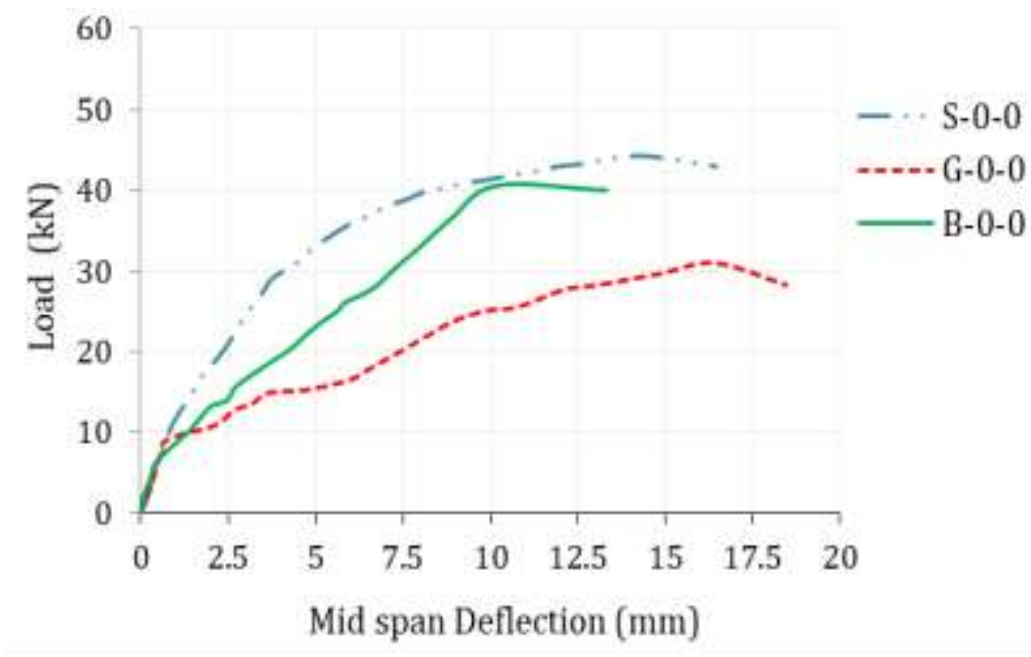

Figure (6): Load-Deflection Curves of tested beams

Comparing results of beams (B-0-0) and (G-0-0) with control beam (S-0-0) are shown in Figure (7) and Table (5) and it was found that:

- Post crack Stiffness, ductility index, and absorbed energy of beam (B-0-0) decreased with percentage $31.8 \%, 41.57 \%$, and $36.42 \%$ respectively than control beam (S-0-0). But initial crack Stiffness of (B-0-0) increased with percentage $4.81 \%$ than control beam (S-0-0).

- Initial crack Stiffness, Post crack Stiffness, and absorbed energy of beam (G-0-0) decreased with percentage $16.74 \%, 60.33 \%$, and $29.79 \%$ respectively than control beam (S-0-0). But ductility index of (G-0-0) increased with percentage $52.83 \%$ than control beam (S-0-0).

Table (5): Stiffness, Ductility Index and Absorbed Energy of tested Beams

\begin{tabular}{|c|c|c|c|c|c|}
\hline Beam & $\begin{array}{c}\text { Reinforcement } \\
\text { Type }\end{array}$ & $\begin{array}{c}\text { Initial crack } \\
\text { stiffness } \\
(\mathbf{K N} / \mathbf{m m})\end{array}$ & $\begin{array}{c}\text { Post crack } \\
\text { stiffness } \\
(\mathbf{K N} / \mathbf{m m})\end{array}$ & $\begin{array}{c}\text { Ductility } \\
\text { Index }(\boldsymbol{\mu d}) \\
\boldsymbol{\%}\end{array}$ & $\begin{array}{c}\text { Absorbed } \\
\text { Energy } \\
(\mathbf{k N} . \mathbf{m m})\end{array}$ \\
\hline S-0-0 & Steel & 12.264 & 6.829 & 18.93 & 568.461 \\
\hline B-0-0 & BFRP & 12.854 & 4.658 & 11.06 & 361.405 \\
\hline G-0-0 & GFRP & 10.211 & 2.709 & 28.93 & 399.114 \\
\hline
\end{tabular}



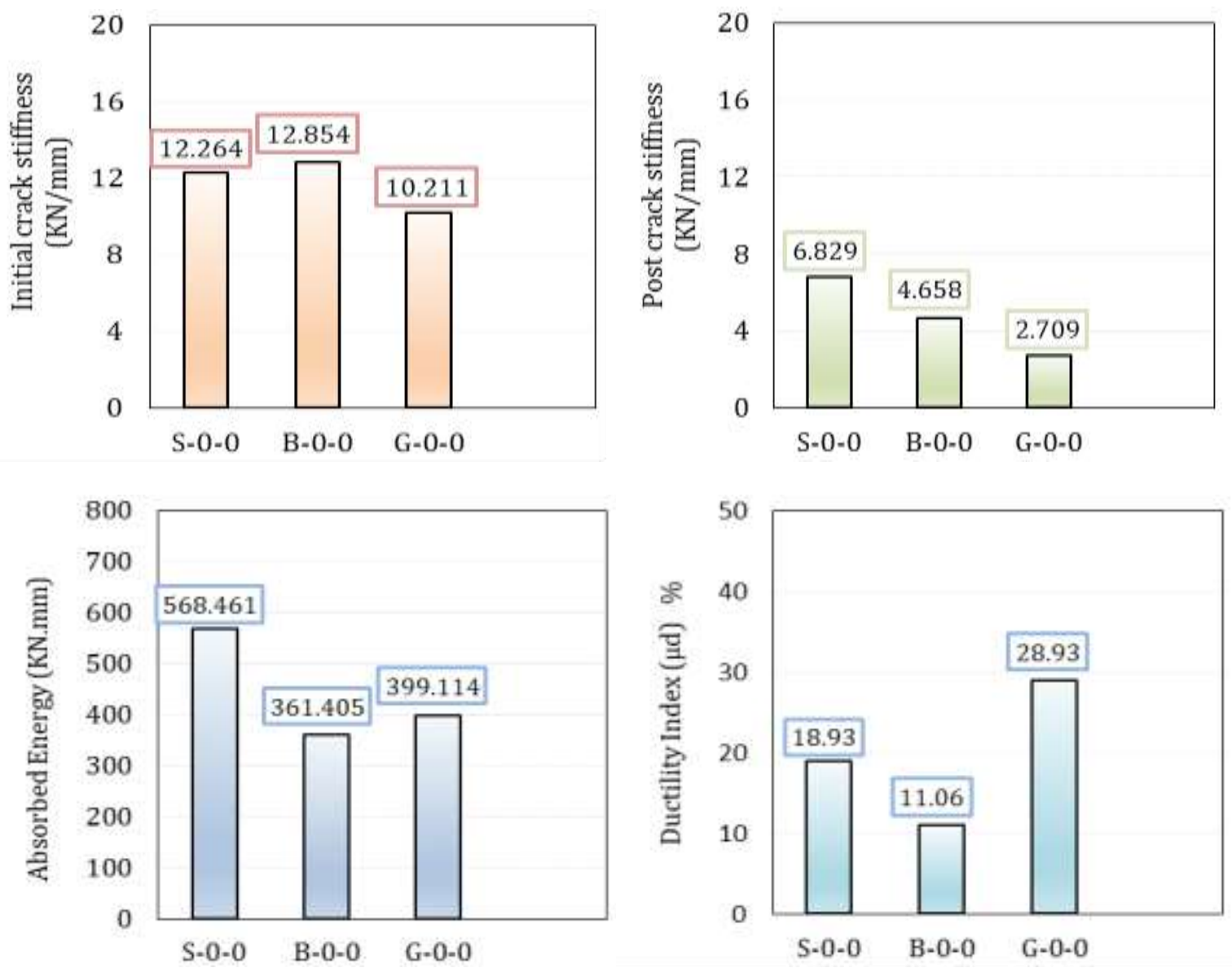

Figure (7): Stiffness, Ductility Index and Absorbed Energy of Tested Beams

\section{Finite Elements Analysis:}

A finite element method FEM was used to simulate the behaviour of beams tested experimentally. ANSYS (14.5) software package was used to conduct the numerical modelling and analyses.

\subsection{Materials Modelling}

- Proper material models are needed to obtain accurate analysis. SOLID65 element requires linear isotropic and multi-linear isotropic material properties to properly model concrete.

- LINK180 element is used for FRP rebar and steel reinforcement in the beams and it requires linear isotropic and Bilinear Isotropic material properties, SOLID 185 element is used to model the loading and support plates to avoid stress concentration and it requires linear isotropic material properties.

\subsection{Model Geometry}

Figure (8) illustrates the geometry of the FE model of the RC beams. 3D isoperimetric element with 16 nodes was used to simulate the beams. Each node has three degrees of freedom translate in $\mathrm{x}, \mathrm{y}$ and $\mathrm{z}$ directions. 


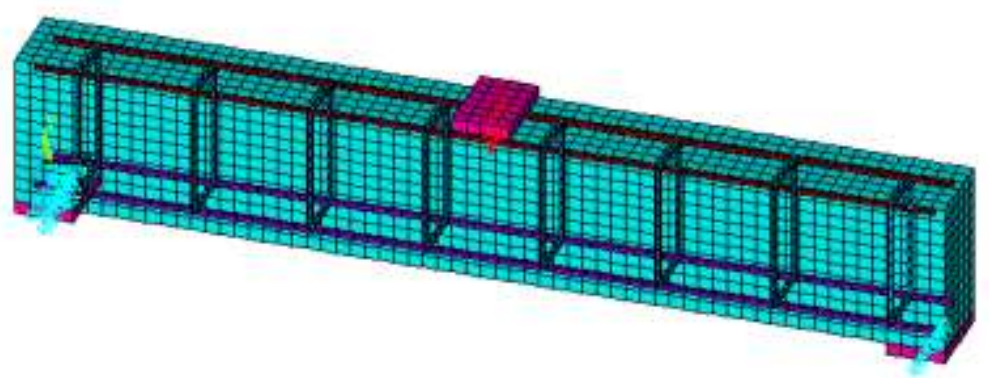

Figure (8): Geometry of the FE beam model.

\subsection{FEA results and discussion:}

The numerical load deflection curves were compared with that of experimental tests for all specimens as shown in Figure (9). The comparisons showed a good agreement between numerical and experimental load-deflection curves. The numerical ultimate loads were slightly higher than that of experimental results. This is probably due to: The bond between the concrete and steel reinforcing is assumed to be perfect (no slip) in the finite element analyses, but for the actual beams the assumption would not be true slip occurs.

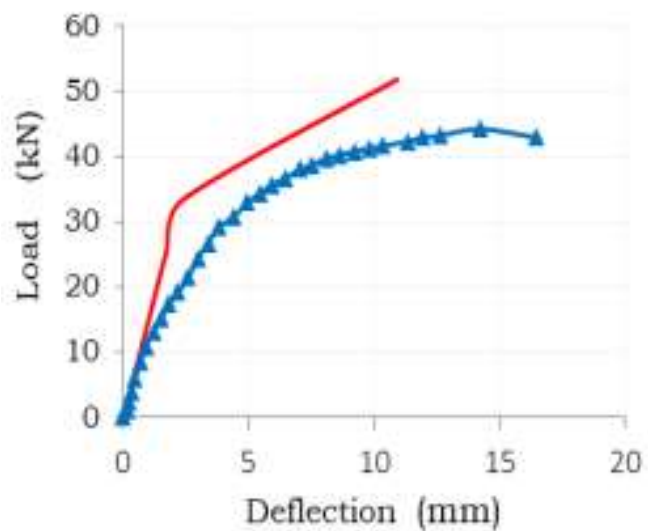

$-\mathrm{S} 1$. ANSYS $\approx \mathrm{S} 1$. $\exp$.

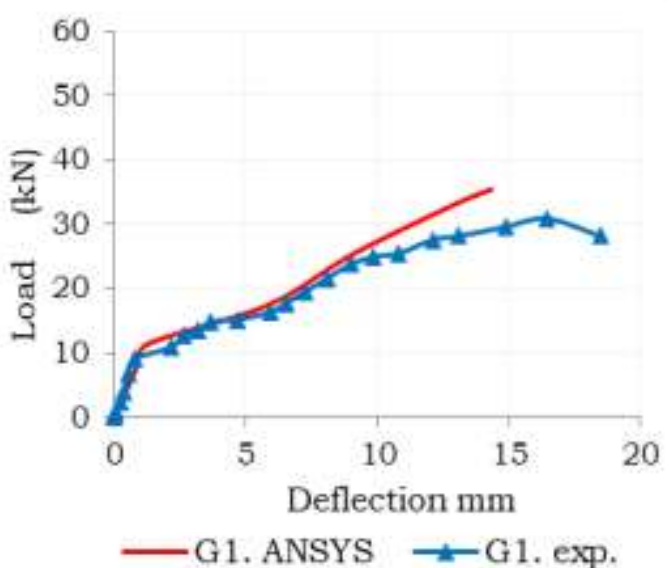

Figure (9): Comparison between Experimental and FE Model.

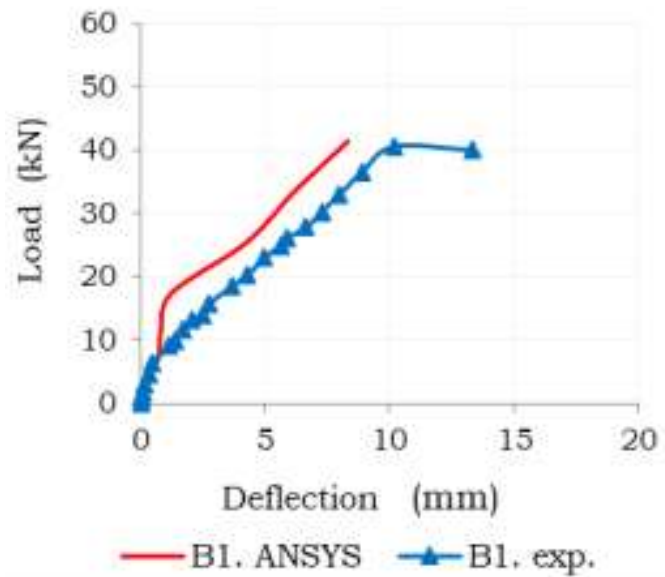

Civ 
Ahmed Hassan / Engineering Research Journal 167 (septamper 2020) C9- C20

\section{Conclusion:}

The following conclusions can be drawn from conducted experimental and Analytical studies:

- It was noted that ultimate load for tested beams reinforced with BFRP and GFRP bars were equal to $40.60 \mathrm{kN}$ and $30.90 \mathrm{KN}$ respectively. Compared to $44.20 \mathrm{KN}$ for beam with steel reinforcement and were on average $8.14 \%$ and $30.10 \%$ lower respectively. Because of Low durability of FRP bars.

- At the same load, it can be seen the increased beam deflections with BFRP and GFRP reinforcement, compared to the steel bars reinforced beam. The reason for the larger values is a lower modulus of elasticity of FRP bars compared to steel bars.

- The results of the finite element models using the ANSYS program showed good agreements with experimental results in terms of load deflection curve, ultimate load.

\section{REFERENECS}

[1] E. Cosenza, G. Manfredi, and R. Realfonzo, "Behavior and modeling of bond of FRP rebars to concrete," Journal of Composites for Construction, vol. 1, pp. 40-51, 1997.

[2] L. Bisby, ISIS educational module 2: An introduction to FRP composites for construction, ISIS Canada, intelligent sensing for innovative structures, a Canadian network of centres of excellence vol. 100. Winnipeg: University of Manitoba, 2003.

[3] D. De Domenico, "RC members strengthened with externally bonded FRP plates: A FE-based limit analysis approach," Composites Part B: Engineering, vol. 71, pp. 159-174, 2015.

[4] L. J. Malvar, "Tensile and bond properties of GFRP reinforcing bars,” Materials Journal, vol. 92, pp. 276$285,1995$.

[5] J. F. Davalos, Y. Chen, and I. Ray, "Effect of FRP bar degradation on interface bond with high strength concrete," Cement and Concrete Composites, vol. 30, pp. 722-730, 2008.

[6] M. A. Ammar, "Bond durability of basalt fibre-reinforced polymers (BFRP) bars under freeze-and-thaw conditions," (Doctoral Dissertation, University Laval), 2014.

[7] M. I. Alam, S. Fawzia, and X. Liu, "Effect of bond length on the behaviour of CFRP strengthened concretefilled steel tubes under transverse impact," Composite Structures, vol. 132, pp. 898-914, 2015.

[8] ACI, 2006. Guide for the Design and Construction of Structural Concrete Reinforced with FRP Bars, ACI 440.1R-06, American Concrete Institute, Farmington Hills, MI.2007.

[9] Bank L.C., 2006. Structural design with FRP materials, Composite for Construction, John Willey and Sons Ltd. 


\section{Ahmed Hassan / Engineering Research Journal 167 (septamper 2020) C9- C20}

[10] S. Tastani and S. Pantazopoulou, "Bond of GFRP bars in concrete: Experimental study and analytical interpretation," Journal of Composites for Construction, vol. 10, pp. 381-391, 2006.

[11] ACI Committee 440. 2003. Guide for the design and construction of concrete reinforced with FRP bars (440.1R-03). American Concrete Institute (ACI), Farmington Hills, Mich.

[12] Katz A (1999) Bond mechanism of FRP rebars to concrete. Materials and Structures 32 (224): 761-768.

[13] Abdalla HA (2002) Evaluation of deflection in concrete members reinforced with fibre reinforced polymer (FRP) bars. Composite Structures 56 (1):63-71.

[14] Alsayed SH (1998) Flexural behaviour of concrete beams reinforced with GFRP bars. Cement and Concrete Composites20 (1):1-11.

[15] Kesse G and Lees J (2007) Experimental behavior of reinforced concrete beams strengthened with Prestressed CFRP shear straps. Journal of Composite for Construction11 (4): 375-383.

[16] Tureyen AK and Frosch RJ (2002) Shear tests of FRP-reinforced concrete beams without stirrups.ACI Structural Journal99 (4):427-434.

[17] Chaallal O and Benmokrane B (1993) Pullout and bond of glass-fibre rods embedded in concrete and cement grout. Materials and Structures26 (3): 167-175.

[18] Ehasani MR, Saadatmanesh H and Tao S (1996) Design recommendation for bond of GFRP rebars to concrete. Journal of Structural Engineering122 (3): 247-254.

[19] Golafshani EM, Rahai A and Sebt MH (2015) artificial neural network and genetic programming for predicting the bond strength of GFRP bars in concrete. Materials and Structures48 (5):1581-1602.

[20] Somboonsong W, Ko FK and Harris HG (1998) Ductile hybrid fiber reinforced plastic reinforcing bar for concrete structures: design methodology.ACI Materials Journal95(6): 655-666.

[21] Altalmas A, El Refai A and Abed F (2015) Bond degradation of basalt fibre-reinforced polymer (BFRP) bars exposed to accelerated aging conditions. Construction and Building Materials81: 162-171.

[22] Tomlinson D and FAM. A (2015) Performance of concrete beams reinforced with basalt FRP for flexure and shear. Journal of Composites for Construction19 (2): 04014036.

[23] Zhang L, Sun Y and Xiong W (2015) Experimental study on the flexural deflections of concrete beam reinforced with basalt FRP bars. Materials and Structures48 (10): 3279-3293.

[24] Ramakrishnan, V., Neeraj, S., and Brik, V. (1998). "Performance evaluation of 3-D basalt fiber reinforced concrete and basalt rod reinforced concrete." Final Rep. NCHRP-45, Transportation Research Board, National Research Council, Washington, DC.

[25] Brik, V. B. (2003). “Advanced concept concrete using Basalt Fiber/Composite bar reinforcement. "Final Rep. for Highway-IDEA Project86, Innovations Deserving Exploratory Analysis (IDEA) Programs, Transportation Research Board, Washington, DC.

[26] Parnas, R., Shaw, M., and Liu, Q. (2007). "Basalt fiber reinforced polymer composites.”Rep. NETCR63, Institute of Materials Science, Univ. of Connecticut, Mansfield, CT. 


\section{Ahmed Hassan / Engineering Research Journal 167 (septamper 2020) C9- C20}

[27] Barris, C., Torres, L., A., Miàs, C., Vilanova, I., 2012. Design of FRP reinforced concrete beams for serviceability requirements, Journal of Civil Engineering and Management 18(6), pp.843-857.

[28] Bischoff, P. H., 2005. Revaluation of deflection prediction for concrete beams reinforced with steel and fiber reinforced polymer bars, Journal of Structural Engineering 131(5), pp. 752-762 